\title{
Detached Leaf Assays for Resistance to Crown Rust Reveal Diversity Within Populations of Avena sterilis
}

\author{
Edyta Paczos-Grzęda, ${ }^{1, \dagger}$ Sylwia Sowa, ${ }^{1}$ Maja Boczkowska, ${ }^{2,3}$ and Tim Langdon ${ }^{4}$ \\ ${ }^{1}$ Institute of Plant Genetics, Breeding and Biotechnology, University of Life Sciences in Lublin, 20-950 Lublin, Poland; ${ }^{2}$ Polish \\ Academy of Sciences Botanical Garden, Center for Biological Diversity Conservation in Powsin, 02-973 Warsaw, Poland; ${ }^{3}$ Plant \\ Breeding and Acclimatization Institute, National Research Institute 05-870 Radzikow, Poland; and ${ }^{4}$ Institute of Biological, \\ Environmental and Rural Sciences, Aberystwyth University, SY23 3EE Aberystwyth, U.K.
}

\begin{abstract}
Crown rust is the most widespread and damaging disease of oat (Avena species). Genetic resistance to the pathogen is the preferred method for crop protection but widespread deployment of limited numbers of major effect genes has promoted the rapid emergence and spread of pathogen races that are able to overcome these genes. Combining genes with even partial resistance may help develop durable cultivars that are less vulnerable to changes in pathogen virulence. Partial resistance is expected to be relatively common in populations of wild species where constant pathogen pressure encourages diversity in host resistance mechanisms, but it may be discarded in conventional screens for major gene resistance. Here, we used a detached leaf assay to detect resistance to the crown rust pathogen, Puccinia coronata Cda. f. sp. avenae, in previously uncharacterized collections of the hexaploid wild oat relative A. sterilis made by the Polish National Centre for Plant Genetic Resources. Many of the accessions were collected in Morocco, the center of diversity for the Avena genus. The detached leaf assessment allowed individual plants to be

challenged with multiple pathotypes and their responses compared with 34 known differentials. Broad-spectrum resistance was identified within accession PL 51855, which behaved as a single major locus on crossing to three cultivars. The locus provided resistance to over 50 rust pathotypes, a greater range than seen for any of the known host resistance $(P c)$ genes. Strong resistance was identified in other accessions, and heterogeneity in response within accessions was common. Several accessions show multiple partial resistance responses that may be of value for developing durable resistance in cultivars. Because the sources of resistance in all but two differential lines were collected outside of Morocco, resistance in all accessions tested here are potentially novel. This study demonstrates that diversity within A. sterilis accessions collected in Morocco could be a very valuable source of resistance to crown rust, and it provides new germplasm for use in resistance breeding programs. Detached leaf assessment provides a valuable first step in the identification of promising candidates in complex gene bank accessions.
\end{abstract}

Crown rust can be a devastating disease of oat (Avena species). It is caused by Puccinia coronata Cda. f. sp. avenae, an obligate biotroph that combines rapid airborne spread with a high level of pathogenic variation as a consequence of asexual reproduction on the crop and a sexual phase on alternate hosts such as buckthorn (Carson 2011; Chong et al. 2011; Simons 1985). Yield losses may reach $40 \%$ or more, with further impact on grain quality (Martinelli et al. 1994; Nazareno et al. 2018). The primary means of control is deployment of host resistance $(P c)$ genes (Gnanesh et al. 2014; Nazareno et al. 2018). Over $100 P c$ genes have been discovered in different Avena species, with diploid, tetraploid, and hexaploid wild oats being used as sources (Chong et al. 2011; Rines et al. 2017). The bulk of these are dominant major effect genes with race specificity. Such specificity tends to be rapidly overcome by novel rust pathotypes, creating an urgent and constant need for replacements (Carson 2011; Simons 1985). Combining race-specific genes may extend their effective useful life in cultivars, but there is also great interest in increasing the use of nonrace-specific resistance, which is not dependent on simple pathogen recognition. Because this typically involves multiple

${ }^{\dagger}$ Corresponding author: E. Paczos-Grzęda;

E-mail: edyta.paczos@up.lublin.pl

Funding: This research was supported by the Ministry of Agriculture and Rural Development of the Republic of Poland (grant 2014-2020: "Crown rust resistance genes pyramiding in oat genome and identification of DNA markers for these genes") and the Biotechnology and Biological Sciences Research Council (grant BB/CSP1730/1).

The author(s) declare no conflict of interest.

Accepted for publication 6 October 2018.

(C) 2019 The American Phytopathological Society genes (each separately providing partial resistance), it is also known generically as quantitative resistance (QR) (Niks et al. 2015). Other descriptions include "field resistance," because its impact is amplified by environmental effects and by the polycyclic character of rust infections during the growing season (Niks et al. 2015), "adult plant resistance" (Peturson 1944), or simply "general resistance" (Thurston 1971). The potential value of $Q R$ for oat breeding has been appreciated for many years, although it has also been known that assessment in glasshouses or disease nurseries may discard levels of resistance that would be valuable under less demanding conditions in the field (Leonard 2002).

QR is expected to be common in wild germplasm (Delph and Kelly 2014). Outside of areas of agricultural monocultures, pathogen diversity is normal and drives the corresponding diversity of host resistance (Karasov et al. 2014). Surveys in Israel, Mexico, and South America have confirmed this pattern in Avena populations (Leonard et al. 2004, 2005). Surprisingly, high diversity did not appear to depend on the presence of the known alternative host that supports the sexual phase (Leonard et al. 2005). Because outcrossing occurs at significant levels $(0.1$ to $12 \%)$ in both wild and cultivated Avena species (Cavan et al. 1998; Imam and Allard, 1965), the genetic basis of QR within populations may be complex and not easily captured by single crosses (Lindhout 2002). Partial resistance has most often been transferred to cultivars as a consequence of genetic analyses of wild species accessions exhibiting strong resistance that were then found to result from multiple loci (reviewed in Nazareno et al. 2018). Typically resistance is reported to separate into distinct loci in about a third of such accessions (Fleischmann et al. 1971; Harder et al. 1980; Kim 1974). This is likely to be an underestimate, as detection of minor loci may require significant effort. For example, the line MN841801 has been analyzed on several occasions as it exhibited continued resistance over many years of trials in disease nurseries. Acevedo et al. (2010) used five field trials and a replicated glasshouse experiment to detect eight partial resistance quantitative trait loci 
(QTL) in MN841801; the study extended previous work that had found four major and three minor QTL (Portyanko et al. 2005). The most recent analysis assigns up to $76 \%$ of the adult plant resistance in this line to QPc.crc-14D (Lin et al. 2014). This is the only single QR locus with a major effect to be claimed for oat thus far, but the multiple additional QTL may have conferred significant protection in the field by acting through complementary mechanisms (Mundt 2014). Another long-lived source of resistance, Pc58, was also originally described as a single locus (Simons et al. 1978) but was subsequently found to result from multiple genes that could be resolved into at least four loci (Hoffman et al. 2006). Because resistance genes are frequently clustered (Michelmore and Meyers 1998), durable resistance conferred by apparent single loci may be found to result from variants in multiple genes with further analyses.

Extensive collections of Avena germplasm are maintained in gene banks worldwide. At least 131,000 accessions are stored by 125 holders in 63 countries (Boczkowska et al. 2016). Almost a quarter of these are accessions of wild species, with the hexaploid A. sterilis L. being the most numerous, represented by over 23,000 accessions. A. sterilis is believed to be the progenitor of cultivated oat and has a wide distribution, characterized as the Mediterranean, Caspian, and Black Sea basins (Loskutov and Rines 2011). Two thirds of the A. sterilis collections originate from Israel, a relatively small geographical region. The majority of $P c$ genes $(n=44)$ are derived from A. sterilis accessions from Israel and other Mediterranean countries (Cabral and Park 2014; Cereal Disease Laboratory 2017; Gnanesh et al. 2014; Šebesta et al. 2003; Simons et al. 1978). In previous work, we (Sowa et al. 2016) and others (Saidi et al. 2005b; Tan and Carson 2013) identified valuable resistance genes from North African collections. Morocco and neighboring countries are of particular interest because they are considered to be the center of diversity for the Avena genus overall (Loskutov 2008), providing a range of $P$. coronata $\mathrm{f}$. sp. avenae hosts. There are also suitable conditions for the pathogen's sexual phase, with both alternate hosts and mild winters. It is therefore of some interest to extend previous screens not only to recover major effect race-specific resistance but also to identify instances of durable resistance that may have built up in wild populations and may be amenable to transfer to cultivars. Because QR genes within populations may be coadapted, or selected by balancing selection to provide complementary specificities, we wished to screen multiple plants from single sites. It is not always clear how accessions have been propagated by gene banks or whether diversity may have been lost during multiplication, but the Polish National Centre for Plant Genetic Resources (IHAR) has collected a number of $A$. sterilis populations from Morocco (https://bankgenow.edu.pl/en/). These accessions retain the diversity of the original population and have not been previously characterized for rust resistance. IHAR also maintains collections from Ukraine and Iran, which provide a useful comparison.

Several approaches have been used to screen the same plant for multiple fungal pathogen isolates, including with different pathogen species (Steffenson et al. 2007), or for responses at different growth stages (Brake and Irwin 1992). Reproducible inocula and growing conditions are difficult to enforce; however, detached leaf assessments have been shown to reproduce rust responses of intact plants in wheat and oat (Felsenstein et al. 1998; Jackson et al. 2008) while presenting more consistent conditions. The detached leaf method has been used successfully to screen for powdery mildew resistance in wild barley accessions (Ames et al. 2015) and was applied here to screen individual seedlings from the IHAR collections.

\section{Materials and Methods}

Pathogen isolates. The standard $P$. coronata isolates CR230, CR241, and CR257 were kindly provided by Dr. J. Menzies (Morden Research and Development Centre, Agriculture and Agri-Food Canada [AAFC], Morden, MB, Canada). Polish isolates were sampled between 2010 and 2017 from infected material from field trial sites at three locations in Poland (Strzelce, Polanowice, and Kopaszewo) as well as the experimental farm of the University of Life Sciences in Lublin (Czesławice, Poland) (Table 1). Each sample was gathered from a different oat field plot. The number of collected samples was determined by the virulence intensity in a given year. Oat leaves with visible disease symptoms were trimmed to a single uredinium and placed into Petri dishes filled with agar $(0.6 \%)$ containing benzimidazole $(3.4 \mathrm{mM})$. Single-uredinia isolates were multiplied in a phytotron on the susceptible oat cultivar, Kasztan (Paczos-Grzęda et al. 2014), based on the host-pathogen methodology by Hsam et al. (1997). Kasztan leaf fragments ( $3 \mathrm{~cm}$ long) were placed onto Petri dishes with water agar medium prepared as above and inoculated in a settling tower by applying 500 to 700 spores of $P$. coronata per $1 \mathrm{~cm}^{2}$. Dishes were then incubated in a phytotron at $18^{\circ} \mathrm{C}$ with $70 \%$ humidity and illuminance of approximately $4 \mathrm{kLx}$ with a $16-\mathrm{h}$ photoperiod. The virulence level of multiplied $P$. coronata isolates was determined on 34 reference oat lines with different crown rust resistance genes. Laboratory tests were carried out on three leaf fragments, each from a different seedling of one Avena genotype using the above-mentioned procedure. Leaves were placed onto 12-well culture plates filled with agar using Kasztan as an infection control in each well.

Detached leaf assays. The host-pathogen test (Hsam et al. 1997) was applied as described in Sowa et al. (2016). Seeds were grown in plug trays filled with a universal substrate containing peat. Ten-dayold leaf fragments were placed onto Petri dishes or in 12-well culture plates with agar $(0.6 \%)$ containing benzimidazole $(3.4 \mathrm{mM})$. Inoculations were performed in a settling tower by applying 500 to 700 spores of $P$. coronata per square centimeter. Dishes or plates were incubated for 10 days in a phytotron at $18^{\circ} \mathrm{C}$ with $70 \%$ humidity and a light intensity of approximately $4 \mathrm{kLx}$ for a 16 -h photoperiod. Crown rust disease symptoms were then evaluated using the 0 to 4 infection type qualitative scale. Scores were transformed as follows: 4 indicates susceptible, with large to moderately large pustules with little or no chlorosis; 3 indicates moderately susceptible, with moderately large pustules surrounded by extensive chlorosis; 2 indicates moderately resistant, with small pustules surrounded by chlorosis or

Table 1. Virulence profile of Puccinia coronata f. sp. avenae isolates used for testing resistance of Avena sterilis accessions

\begin{tabular}{|c|c|c|c|}
\hline Isolate no. & Phenotype code ${ }^{a}$ & Virulence to standard differentials ${ }^{\mathbf{b}}$ & Virulence to supplemental differentials ${ }^{\mathrm{c}}$ \\
\hline 3.2 & SQLT & $\begin{array}{l}\text { Pc38, Pc39, Pc40, Pc45, Pc46, Pc51, Pc54, Pc56, } \\
\text { Pc62, Pc64 }\end{array}$ & $\begin{array}{l}\text { Pc14, Pc35, Pc36, Pc55, Pc61, Pc63, Pc70, Pc96, Pc97, Pc98, Pc101, } \\
\text { Pc103-1 }\end{array}$ \\
\hline 11.1 & QGBT & Pc39, Pc40, Pc45, Pc54, Pc56, Pc62, Pc64 & Pc36, Pc55, Pc61, Pc70, Pc103-1 \\
\hline 22.1 & LNDR & Pc38, Pc40, Pc48, Pc54, Pc56, Pc58, Pc64 & Pc35, Pc63, Pc94, Рc96, Рc97, Рc103-1 \\
\hline $51 \mathrm{U}$ & SBLP & Pc40, Pc45, Pc46, Pc51, Pc54, Pc62, Pc64 & Pc14, Pc35, Pc57, Pc96, Pc97, Pc98, Pc101, Pc104 \\
\hline $94 \mathrm{U}$ & NJBP & Pc39, Pc40, Pc46, Pc48, Pc54, Pc62, Pc64 & Pc36, Pc55, Pc57, Pc61, Pc70, Pc71, Pc94, Pc96, Pc97, Pc98, Pc103-1 \\
\hline CR230 & LQCB & Pc38, Pc39, Pc40, Pc59 & Pc14, Pc35, Pc36, Pc55, Pc57, Pc60, Pc61, Pc63, Pc70, Pc71, Pc91 \\
\hline CR241 & DSGB & Pc38, Pc39, Pc46, Pc48, Pc52 & Pc14, Pc36, Pc55, Pc61, Pc63, Pc70, Pc71, Pc103-1 \\
\hline CR257 & BRBG & Pc38, Pc39, Pc56, Pc68 & Pc36, Pc55, Pc61, Pc63, Pc70, Pc71, Pc94 \\
\hline $50 \_822$ & TBLP & Pc40, Pc45, Pc46, Pc50, Pc51, Pc54, Pc62, Pc64 & Pc14, Pc57, Pc96, Pc97, Pc98, Pc103 \\
\hline 58_172 & BLDL & Pc38, Pc58 & Pc35, Pc63, Pc97 \\
\hline
\end{tabular}

\footnotetext{
a Phenotype code based on the standard differentials set.

${ }^{b}$ Chong et al. (2000).

${ }^{\mathrm{c}}$ Chong et al. (2011).
} 
necrosis; 1 indicates resistant, with chlorotic or necrotic flecking; and 0 indicates highly resistant, with no visible reaction (Carson 2009; Murphy 1935; Sowa et al. 2016; see Nazareno et al. 2018 for an illustration).

$\boldsymbol{P c}$ standards. Reactions to the isolate infections of 34 differential oat lines and the A. sterilis accessions were grouped into two classes: phenotypes described as susceptible and moderately susceptible were considered as susceptible (high infection type, virulent reaction), and the remainder as resistant (low infection type, avirulent). Based on an assessment of every single seedling resistance on five applied isolates, infection profiles (IPs) of the A. sterilis accessions were assigned. Every IP was assigned a letter code. In order to select

Table 2. Avena sterilis accession list

\begin{tabular}{|c|c|c|c|}
\hline No. & IHAR no. ${ }^{\mathbf{a}}$ & Acquisition date & Country of origin ${ }^{b}$ \\
\hline 1 & PL 51555c & 1985 & MAR \\
\hline 2 & PL $51822^{c}$ & 1993 & N/A \\
\hline 3 & PL 51827c & 1993 & MAR \\
\hline 4 & PL 51829c & 1993 & MAR \\
\hline 5 & PL 51834c & 1993 & N/A \\
\hline 6 & PL 51844c & 1993 & N/A \\
\hline 7 & PL 51855 & 1993 & MAR \\
\hline 8 & PL 52203c & 1997 & N/A \\
\hline 9 & PL 52337c & 2001 & N/A \\
\hline 10 & PL 52356 & 2001 & UKR \\
\hline 11 & PL 51557d & 1985 & MAR \\
\hline 12 & PL 51559 & 1985 & MAR \\
\hline 13 & PL 51565 & 1985 & MAR \\
\hline 14 & PL 51589 & N/A & MAR \\
\hline 15 & PL 51818d & 1993 & MAR \\
\hline 16 & PL 51823 & 1993 & MAR \\
\hline 17 & PL 51828d & 1993 & MAR \\
\hline 18 & PL 51832 & 1993 & MAR \\
\hline 19 & PL 51836 & 1993 & MAR \\
\hline 20 & PL 51837d & 1993 & MAR \\
\hline 21 & PL 51838d & 1993 & MAR \\
\hline 22 & PL 51839d & 1993 & MAR \\
\hline 23 & PL 51840d & 1993 & MAR \\
\hline 24 & PL 51841d & 1993 & MAR \\
\hline 25 & PL 51851d & 1993 & MAR \\
\hline 26 & PL 51856 & 1993 & MAR \\
\hline 27 & PL 51857d & 1993 & MAR \\
\hline 28 & PL 51860 & 1993 & MAR \\
\hline 29 & PL 52105 & 1995 & N/A \\
\hline 30 & PL 52106 & 1995 & N/A \\
\hline 31 & PL 52108 & 1995 & N/A \\
\hline 32 & PL 52109 & 1995 & N/A \\
\hline 33 & PL 52110 & 1995 & N/A \\
\hline 34 & PL 52111 & 1995 & N/A \\
\hline 35 & PL 52205 & 1997 & N/A \\
\hline 36 & PL 52209 & 1997 & N/A \\
\hline 37 & PL 52212 & 1997 & N/A \\
\hline 38 & PL 52217d & 1997 & N/A \\
\hline 39 & PL 52278d & 2000 & N/A \\
\hline 40 & PL 52353 & 2001 & UKR \\
\hline 41 & PL 52355 & 2001 & UKR \\
\hline 42 & PL 52363 & 2001 & UKR \\
\hline 43 & PL 52435 & 2004 & UKR \\
\hline 44 & PL 52442 & N/A & N/A \\
\hline 45 & PL 52459 & 2006 & N/A \\
\hline 46 & PL 52460 & 2006 & N/A \\
\hline 47 & PL 52461 & 2006 & N/A \\
\hline 48 & PL 52462 & 2006 & N/A \\
\hline 49 & PL 501552 & 2004 & IRN \\
\hline 50 & PL 502692 & 2005 & UKR \\
\hline 51 & PL 502695 & 2004 & IRN \\
\hline
\end{tabular}

${ }^{a}$ IHAR $=$ Polish National Centre for Plant Genetic Resources.

${ }^{\mathrm{b}} \mathrm{MAR}=$ Morocco, N/A = Not available, UKR = Ukraine, and IRN = Iran

c Accessions analyzed in the first screen.

d Accessions analyzed in both screens. genotypes with crown rust resistance conditioned by novel genes, the IPs of differential lines were compared with the IPs ascribed to analyzed $A$. sterilis accessions.

Plant material. Seeds of A. sterilis were obtained from the National Centre for Plant Genetic Resources (Radzików, Poland) (Table 2). Accessions were acquired during field expeditions in Morocco (22 accessions), Ukraine (six accessions), and Iran (two accessions) between 1985 and 2006, or they were provided without information about collection sites ( 21 accessions). Expedition collections aimed to capture the range of observed variation, with all seeds from a single collection site combined to form a bulk sample with a single accession number (W. Podyma, personal communication). Whenever possible, a random sample of 50 to 100 individual plants was collected to provide a $95 \%$ probability of obtaining at least one copy of any allele that occurs with a frequency greater than 0.05 (Marshall and Brown 1975).

Thirty-four differential oat lines with single resistance genes were used to characterize the virulence of Polish isolates and for comparison with IHAR material. Differentials for genes Pc58, Pc59, Pc60, and Pc61 were represented by cultivars TAM-O-301, TAM-O-312, Coker227, and Coker234, respectively (Simons et al. 1978). The near-isogenic lines Pc35, Pc38, Pc39, Pc40, Pc45, Pc46, Pc48, Pc50, Pc54, Pc55, Pc56, Pc57, Pc62, Pc63, Pc64, Pc68, Pc91, Pc94, Pc96, Pc97, Pc98, Pc101, Pc103-1, and Pc104 were developed at the Cereal Research Centre (AAFC, Winnipeg, MB, Canada) and the differentials Pc14, Pc36, Pc51, Pc52, Pc70, and Pc71 were created at Iowa State University (Ames, IA) (Carson 2011; Chong et al. 2011; Menzies et al. 2015).

\section{Results}

The occurrence of $P$. coronata was monitored at selected field trial and production sites across central and eastern Poland between 2010 and 2017 (Strzelce, Polanowice, Kopaszewo, and Czesławice) (Table 1). Thirty-four differential resistance lines of oat were used to test for virulence to known resistance genes that may be deployed in the crop, and Polish rust isolates were compared with virulent races isolated in Canada. The Polish races were found to have overcome

Table 3. Characteristics of the initial set of Avena sterilis accession reactions on inoculation with three Puccinia coronata isolates

\begin{tabular}{|c|c|c|c|}
\hline \multirow[b]{2}{*}{ Plant identifier } & \multicolumn{3}{|c|}{$P$. coronata race $^{\mathrm{a}}$} \\
\hline & 3.2 & 11.1 & 22.1 \\
\hline PL 51555 & $\mathrm{R}$ & MR, $\mathrm{R}$ & $S$ \\
\hline PL 51557_a & $\mathrm{S}$ & $\mathrm{S}$ & $\mathrm{S}$ \\
\hline PL 51557_b & S & $\mathrm{S}$ & $S$ \\
\hline PL 51818 & $\mathrm{~S}$ & $\mathrm{~S}$ & $\mathrm{~S}$ \\
\hline PL 51822_a & HR & $\mathrm{R}, \mathrm{S}$ & S \\
\hline PL 51822_b & $\mathrm{S}$ & $\mathrm{S}$ & $\mathrm{S}$ \\
\hline PL 51827 & $\mathrm{~S}$ & $\mathrm{R}$ & $\mathrm{S}$ \\
\hline PL 51828 & $\mathrm{~S}$ & $\mathrm{R}$ & $\mathrm{S}$ \\
\hline PL 51829 & S & $\mathrm{S}$ & $\mathrm{S}$ \\
\hline PL 51834 & $\mathrm{~S}$ & $\mathrm{~S}$ & $\mathrm{~S}$ \\
\hline PL 51837 & $\mathrm{~S}$ & $\mathrm{~S}$ & $\mathrm{~S}$ \\
\hline PL 51840 & $\mathrm{~S}$ & MS & $\mathrm{S}$ \\
\hline PL 51841 & $\mathrm{R}$ & HR & $\mathrm{R}, \mathrm{S}$ \\
\hline PL 51844 & $\mathrm{~S}$ & $\mathrm{~S}$ & $\mathrm{~S}$ \\
\hline PL 51851_a & HR & $\mathrm{R}, \mathrm{HR}$ & $S$ \\
\hline PL 51851_b & S & $\mathrm{R}, \mathrm{HR}$ & S \\
\hline PL 51856 & S & $\mathrm{S}$ & S \\
\hline PL 51857 & S & $\mathrm{S}$ & S \\
\hline PL 52217 & S & $\mathrm{S}$ & $\mathrm{S}$ \\
\hline PL 51855_a & HR & HR & HR \\
\hline PL 51855_b & S & $\mathrm{S}$ & $S$ \\
\hline PL 52203 & HR & $\mathrm{S}$ & HR \\
\hline PL 52278 & $\mathrm{~S}$ & $\mathrm{~S}$ & S \\
\hline PL 52337 & $\mathrm{~S}$ & $\mathrm{~S}$ & $\mathrm{~S}$ \\
\hline PL 52356 & $\mathrm{~S}$ & $\mathrm{~S}$ & $\mathrm{~S}$ \\
\hline
\end{tabular}

${ }^{a}$ Resistance phenotype: $\mathrm{R}=$ resistant, $\mathrm{MR}=$ moderately resistant, $\mathrm{S}=$ susceptible, $\mathrm{HR}=$ highly resistant, and MS = moderately susceptible. 
a high proportion of the standard differential resistances, with each isolate showing virulence against two to 10 of the standards. Most significantly, seven standard differential genes (Pc45, Pc50, Pc51, $P c 54, P c 58, P c 62$, and Pc64) that provided protection to the three Canadian isolates (CR230, CR241, and CR257) had been overcome by Polish races, with virulence also seen against five of the variable differential genes (Pc96, Pc97, Pc98, Pc101, and Pc104). Only three differential genes that had been overcome by Canadian races remained effective against the Polish isolates (Pc52, Pc59, and $P c 91)$. Seven Polish isolates were identified, which in various combinations with the Canadian races allowed testing of the majority of standard virulence responses (Table 1). The large range of specificities identified by a small number of isolates allowed comprehensive assessment of resistance on fragments of single leaves in the subsequent tests.

IHAR provided accessions of A. sterilis collected during expeditions to Morocco, Iran, and Ukraine between 1985 and 2006. Initially a set of 21 accessions was selected (Tables 2 and 3). Fifteen were of Moroccan origin. Each accession represented an A. sterilis population and thus may contain multiple genotypes. Four accessions (PL 51557, PL 51851, PL 51822, and PL 51855) were found to contain visible morphological variants and were divided into two subaccessions. Three Polish rust isolates, 3(2), 11(1), and 22(1), were chosen as representative of emerging virulent races at the time of initial experiments (isolated in 2010, 2012, and 2013, respectively), and detached leaf assessments from three seedlings per accession were carried out to determine susceptibility. The 34 oat differential lines were tested at the same time to compare responses. The three rust isolates used were virulent against 26 of 34 tested differentials (Table 1). Sixteen of the twenty-five samples tested were susceptible to all three Polish races used, eight were resistant to one or two races, and subaccession PL 51855a was evaluated as highly resistant to all three. PL 51855a was taken for further genetic analysis (below).

Three of the four accessions showing morphological variation also showed contrasting resistance profiles. Two of the three were Moroccan accessions, with four more Moroccan accessions also showing resistance. It seemed likely that screening greater numbers of each accession would recover additional resistance, so the number of seedlings used was increased to 10 for a second set of screens. Ten of the original panels were repeated, with 31 additional accessions. Twelve of these new samples were Moroccan, and five were from Ukraine. Five $P$. coronata isolates were used, which in combination allowed testing of an additional five differential lines compared with the initial rust set $(P c 52, P c 59, P c 60, P c 68$, and $P c 91)$. The only

Table 4. Characteristics of the second set of Avena sterilis accessions reaction on inoculation with five Puccinia coronata isolates

\begin{tabular}{|c|c|c|c|c|c|c|}
\hline \multirow[b]{2}{*}{ Plant identifier } & \multicolumn{5}{|c|}{ P. coronata race a $^{a}$} & \multirow[b]{2}{*}{ Single seedling IP (seedlings, $n)^{\mathbf{b}}$} \\
\hline & CR241 & 94U & CR230 & $51 \mathrm{U}$ & CR257 & \\
\hline PL 51557 & $\mathrm{~S}$ & $\mathrm{~S}, \mathrm{MS}$ & $\mathrm{S}, \mathrm{MR}$ & $\mathrm{S}, \mathrm{MS}$ & $S$ & $\mathrm{~A}(9), \mathrm{E}(1)$ \\
\hline PL 51559 & $\mathrm{~S}, \mathrm{R}$ & $\mathrm{S}, \mathrm{R}$ & $\mathrm{S}, \mathrm{R}$ & S, MS, R & $\mathrm{S}, \mathrm{HR}$ & A (4), B (1), D (1), R (1), S (1), L (2) \\
\hline PL 51565 & $\mathrm{~S}$ & $\mathrm{~S}$ & $\mathrm{~S}$ & $\mathrm{~S}$ & $S$ & A (10) \\
\hline PL 51589 & $\mathrm{~S}$ & MR, R & $\mathrm{S}$ & MR, R & $\mathrm{S}$ & $\mathrm{L}(10)$ \\
\hline PL 51818 & $\mathrm{~S}$ & S, MS, R & MS, MR & $\mathrm{S}$ & S, MS, MR & A (4), D (2), C (2), F (2) \\
\hline PL 51823 & $\mathrm{~S}$ & $\mathrm{~S}$ & $\mathrm{~S}$ & $\mathrm{~S}$ & S, MS & A (10) \\
\hline PL 51832 & $\mathrm{~S}, \mathrm{MS}, \mathrm{MR}, \mathrm{R}$ & $\mathrm{S}$ & MR, $\mathrm{R}$ & $\mathrm{S}, \mathrm{MS}$ & $\mathrm{S}, \mathrm{R}$ & $\mathrm{P}(5), \mathrm{K}(4), \mathrm{W}(1)$ \\
\hline PL 51828 & $\mathrm{~S}$ & $\mathrm{~S}$ & $\mathrm{~S}$ & S, MS & $\mathrm{S}$ & A (10) \\
\hline PL 51836 & $\mathrm{HR}$ & $\mathrm{R}$ & $\mathrm{HR}$ & HR & $\mathrm{R}, \mathrm{HR}$ & $\mathrm{T}(10)$ \\
\hline PL 51837 & $\mathrm{~S}$ & S, MS, R & $\mathrm{S}$ & $\mathrm{S}, \mathrm{MS}$ & $S$ & A (7), C (3) \\
\hline PL 51838 & $\mathrm{~S}$ & MS, R & $\mathrm{S}$ & S, MS & S & $\mathrm{A}(6), \mathrm{C}(3), \mathrm{K}(1)$ \\
\hline PL 51839 & $\mathrm{~S}, \mathrm{MR}, \mathrm{R}$ & $\mathrm{S}$ & S, MS, MR & S, MS, R & MS & A (6), E (2), I (1), H (1) \\
\hline PL 51840 & $\mathrm{~S}$ & $\mathrm{~S}$ & $\mathrm{~S}$ & S, MS, MR & MS & $\mathrm{A}(9), \mathrm{E}(1)$ \\
\hline PL 51841 & $\mathrm{~S}, \mathrm{HR}$ & MS, MR, R & S, MS, R & $\mathrm{S}, \mathrm{MS}, \mathrm{MR}, \mathrm{R}$ & $\mathrm{S}, \mathrm{MR}, \mathrm{R}$ & $\mathrm{A}(1), \mathrm{C}(4), \mathrm{D}(1), \mathrm{U}(1), \mathrm{X}(1), \mathrm{Y}(2)$ \\
\hline PL 51851 & $\mathrm{HR}, \mathrm{S}$ & MS, R & S, MS, R & MS, R & $\mathrm{S}, \mathrm{R}, \mathrm{HR}$ & $\mathrm{A}(2), \mathrm{T}(3), \mathrm{C}(2), \mathrm{F}(1), \mathrm{X}(1), \mathrm{M}(1)$ \\
\hline PL 51856 & $\mathrm{~S}, \mathrm{HR}$ & $\mathrm{S}, \mathrm{MR}, \mathrm{R}$ & $\mathrm{S}, \mathrm{HR}$ & $\mathrm{S}, \mathrm{R}$ & $\mathrm{S}, \mathrm{R}$ & $\mathrm{T}(8), \mathrm{X}(1), \mathrm{A}(1)$ \\
\hline PL 51857 & $\mathrm{~S}$ & $S$ & $\mathrm{~S}$ & $\mathrm{~S}$ & S, MS & $\mathrm{A}(10)$ \\
\hline PL 51860 & $\mathrm{~S}, \mathrm{MS}$ & MS, R & $\mathrm{S}$ & $\mathrm{S}$ & S, MS, HR & $\mathrm{A}(3), \mathrm{C}(6), \mathrm{F}(1)$ \\
\hline PL 52105 & $\mathrm{~S}$ & MS, R & $\mathrm{S}$ & $\mathrm{S}, \mathrm{MS}$ & $\mathrm{S}, \mathrm{HR}$ & $\mathrm{A}(7), \mathrm{C}(2), \mathrm{F}(1)$ \\
\hline PL 52106 & $\mathrm{~S}$ & $\mathrm{~S}, \mathrm{R}$ & MS, MR, R & $\mathrm{S}$ & $\mathrm{S}, \mathrm{R}$ & $\mathrm{A}(7), \mathrm{K}(1), \mathrm{D}(1), \mathrm{G}(1)$ \\
\hline PL 52108 & $\mathrm{~S}$ & $\mathrm{~S}, \mathrm{R}$ & $\mathrm{S}$ & $\mathrm{S}, \mathrm{MS}$ & $S$ & $\mathrm{~A}(9), \mathrm{C}(1)$ \\
\hline PL 52109 & $\mathrm{~S}$ & $\mathrm{~S}, \mathrm{R}$ & $\mathrm{S}$ & S, MS, R & $S$ & $\mathrm{~A}(8), \mathrm{E}(1), \mathrm{C}(1)$ \\
\hline PL 52110 & $\mathrm{~S}$ & $\mathrm{R}$ & $\mathrm{S}$ & MR, R & S, MS & $\mathrm{L}(10)$ \\
\hline PL 52111 & $\mathrm{~S}, \mathrm{MS}, \mathrm{R}$ & $\mathrm{S}, \mathrm{R}$ & S, MS, R & $\mathrm{S}, \mathrm{R}$ & $\mathrm{S}, \mathrm{R}$ & A (6), C (1), W (2), S (1) \\
\hline PL 52205 & $\mathrm{~S}$ & $\mathrm{~S}$ & $\mathrm{~S}, \mathrm{MR}, \mathrm{R}$ & S, MS & $S$ & $\mathrm{~A}(7), \mathrm{D}(3)$ \\
\hline PL 52209 & $S$ & $\mathrm{~S}$ & MR, $R$ & $\mathrm{~S}$ & $\mathrm{~S}, \mathrm{HR}$ & $\mathrm{G}(4), \mathrm{D}(6)$ \\
\hline PL 52212 & $\mathrm{~S}$ & S, MS, R & $\mathrm{S}$ & $\mathrm{S}, \mathrm{MS}, \mathrm{MR}, \mathrm{R}$ & $\mathrm{S}, \mathrm{MR}$ & $\mathrm{A}(3), \mathrm{E}(5), \mathrm{L}(1), \mathrm{G}(1)$ \\
\hline PL 52217 & S, MS, MR & $\mathrm{S}$ & $\mathrm{S}$ & $\mathrm{S}, \mathrm{MS}$ & $S$ & A (9), B (1) \\
\hline PL 52278 & S, MS & $\mathrm{S}$ & $\mathrm{S}, \mathrm{MR}, \mathrm{R}$ & $\mathrm{S}, \mathrm{MS}$ & S & $\mathrm{A}(5), \mathrm{D}(5)$ \\
\hline PL 52353 & $\mathrm{~S}$ & S, MS, MR, R & $\mathrm{S}$ & S, MS & $\mathrm{S}$ & $\mathrm{A}(7), \mathrm{C}(3)$ \\
\hline PL 52355 & $\mathrm{~S}$ & $\mathrm{~S}$ & $\mathrm{~S}, \mathrm{MR}$ & S, MR & $\mathrm{S}$ & $\mathrm{A}(9), \mathrm{N}(1)$ \\
\hline PL 52363 & $\mathrm{~S}$ & $\mathrm{~S}$ & $\mathrm{~S}$ & S, MS & S & $\mathrm{A}(10)$ \\
\hline PL 52435 & $\mathrm{~S}$ & $\mathrm{~S}$ & S & $\mathrm{S}, \mathrm{MR}$ & S & $\mathrm{A}(5), \mathrm{E}(5)$ \\
\hline PL 52442 & $\mathrm{~S}$ & S, MS, MR & $\mathrm{S}, \mathrm{R}$ & S, MS, R & $\mathrm{S}, \mathrm{R}$ & $\mathrm{A}(4), \mathrm{C}(2), \mathrm{D}(1), \mathrm{L}(1), \mathrm{K}(1), \mathrm{F}(1)$ \\
\hline PL 52459 & $\mathrm{~S}$ & MS, R & $\mathrm{S}$ & S, MS & $S$ & $\mathrm{~A}(4), \mathrm{C}(6)$ \\
\hline PL 52460 & $\mathrm{~S}$ & S, MS, R & $\mathrm{S}$ & $\mathrm{S}$ & S & $\mathrm{A}(8), \mathrm{C}(2)$ \\
\hline PL 52461 & $\mathrm{~S}$ & S, MS & $\mathrm{S}$ & $\mathrm{S}$ & S & $\mathrm{A}(10)$ \\
\hline PL 52462 & $\mathrm{~S}$ & $\mathrm{~S}$ & $\mathrm{~S}$ & S, MS & S & A (10) \\
\hline PL 501552 & $\mathrm{~S}$ & S, MS, R & $\mathrm{S}$ & S, MS & S & A (9), C (1) \\
\hline PL 502692 & $\mathrm{~S}$ & $\mathrm{~S}$ & $\mathrm{~S}$ & S, MS, MR & S & $\mathrm{A}(9), \mathrm{E}(1)$ \\
\hline PL 502695 & S, MS & S, MS, R & $\mathrm{S}$ & S, MS & S & $\mathrm{A}(9), \mathrm{C}(1)$ \\
\hline
\end{tabular}

\footnotetext{
${ }^{a}$ Resistance phenotype: $\mathrm{S}=$ susceptible, $\mathrm{MS}=$ moderately susceptible, $\mathrm{MR}=$ moderately resistant, $\mathrm{R}=$ resistant, and $\mathrm{HR}=$ highly resistant (no visible reaction).
}

${ }^{\mathrm{b}}$ Infection pattern determined for five tested isolates presented in Table 5. IP = infection profile. 
differentials not susceptible to one or more isolates were $P c 50$ and $P c 58$. The most aggressive isolate used was the Polish pathotype $94 \mathrm{U}(63)$, isolated in 2015, which gave a susceptible response on 18 of 34 evaluated $P c$ genes. CR230 and 51U(22) isolates overcame the resistance of 15 reference lines, whereas CR241 and CR257 were virulent toward 13 and $11 P c$ lines, respectively (Table 1).

The responses of the $410 \mathrm{~A}$. sterilis seedlings in the host-pathogen tests were scored from susceptible to highly resistant (Table 4; displayed graphically in simplified form in Figure 1). Thirty-one of the $A$. sterilis accessions (76\%) displayed heterogeneous phenotypes, with the specific response of single seedlings within accessions varying from fully susceptible to fully resistant in some cases. Seven accessions $(17 \%)$ were completely susceptible on all tested $P$. coronata f. sp. avenae races. In eight accessions (20\%), only one seedling was rated as resistant or moderately resistant to one or two crown rust races; in three more, two to three seedlings displayed some level of resistance, mostly to $94 \mathrm{U}(63)$ or CR230. For five accessions, at least half the seedlings displayed a common pattern of resistance on one $P$. coronata f. sp. avenae pathotype (mainly 94U, 51U, or CR230). Three accessions showed consistent resistance to two or more pathotypes across all seedlings, while seedlings in 10 accessions (24\%) were predominantly resistant but with a range of susceptibilities.
Of the 10 accessions repeated in the second screen, no resistance was found in four cases that were initially scored as susceptible, a single resistant seedling was found in one initially susceptible accession, and broad resistance was found in nine seedlings of PL 51856 that had been designated susceptible. The final two repeated accessions, PL 51841 and PL 51851, showed complex resistance patterns.

The 14 accessions showing significant levels of resistance (more than half the seedlings) were predominantly of Moroccan origin (10 of 18 Moroccan accessions). None were from the five Ukrainian accessions tested. It was striking that the Moroccan accessions overall displayed complex resistance patterns consistent with the presence of multiple variants in each population, while the Ukrainian accessions displayed either complete susceptibility (one accession) or one to five seedlings showing the same resistance pattern per accession (four samples). Three Moroccan accessions showed complete susceptibility, three showed a consistent resistance profile for all seedlings, and three more contained one to three seedlings with the same resistance pattern within the accession. Nine contained more than one resistance profile.

The differential control lines containing individual $P c$ genes could show resistance to single or multiple rust isolates, with $P c 50$ and Pc58 being resistant to all five (Table 5), so the heterogeneous

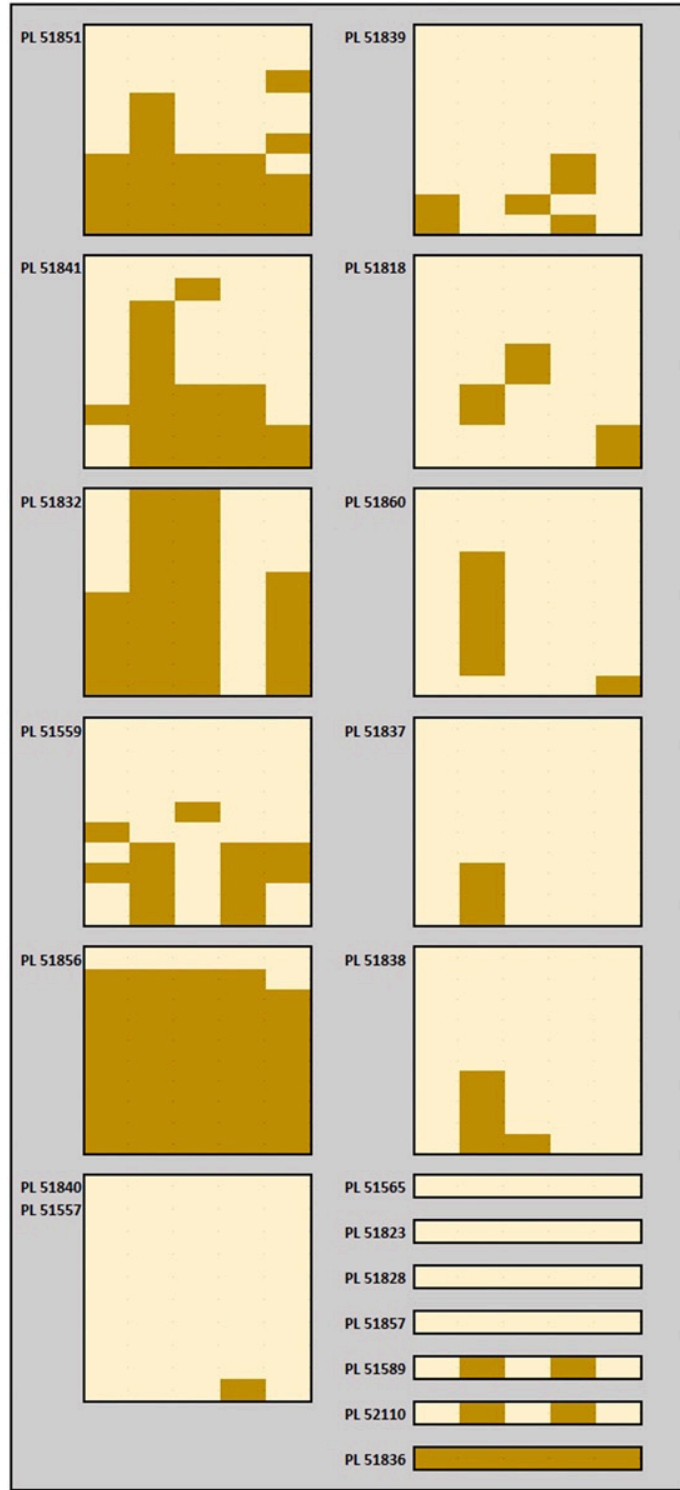

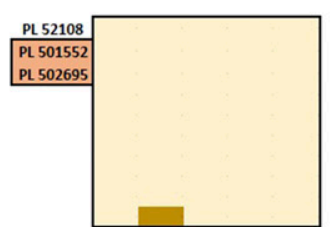
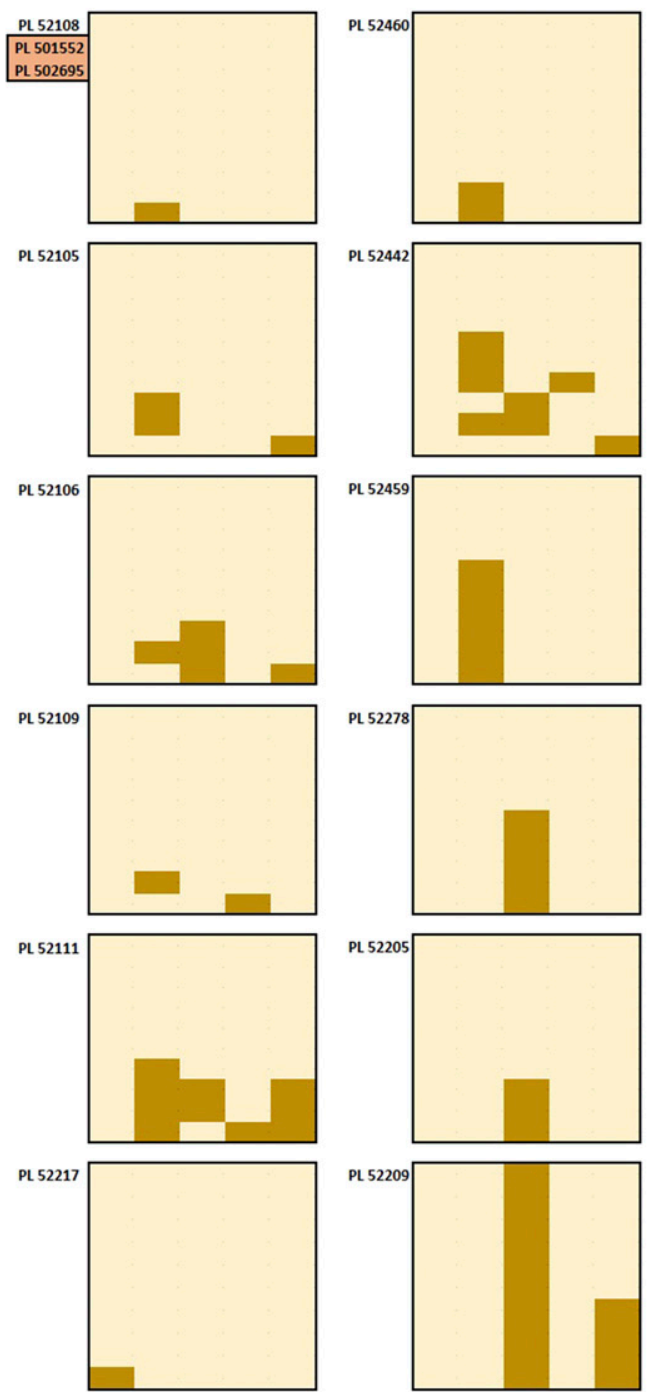
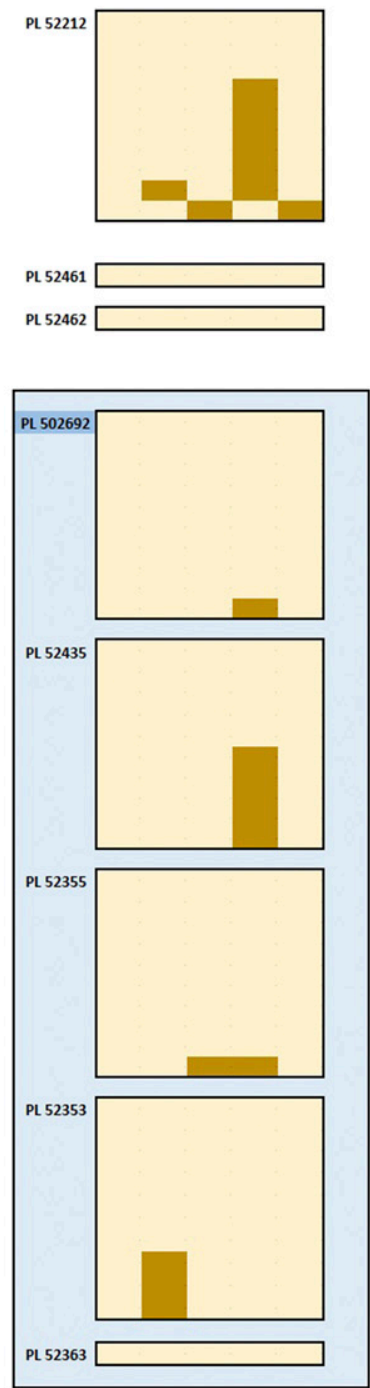

Fig. 1. Resistance of Avena sterilis accessions to crown rust isolates. Ten seedlings of each accession (vertical axis) were challenged with five Puccinia coronata pathotypes (left to right: CR241, 94U, CR230, 51U, and CR257). Resistance is scored as for Table 4, with categories combined to show only the most significant avirulent reactions. Single rows indicate that all seedlings within the accession showed the same response. Accessions with the same composition are labeled (PL 51860 and PL 51557, PL 52108, and both Iranian accessions PL 501552 and PL 502695). Moroccan accessions are grouped in the left box, and Ukrainian accessions are in the right box. 
patterns seen within many accessions are difficult to interpret in the absence of genetic analyses. A number of accessions appear to contain novel specificities. Six seedlings of PL 51860 showed resistance only to pathotype $94 \mathrm{U}$, while three were susceptible to all rust isolates and the last was resistant only to CR257. No differential showed resistance only to $94 \mathrm{U}$ and the consistent response of most seedlings of PL 51860 indicates that this is likely a specific and new response. In other cases, a simple additive effect of multiple resistances could explain the pattern seen. For example, accession PL 52209 gave rise to six seedlings of profile D (resistance only to CR203) and four of profile G (resistance to CR203 and CR257). While Pc46 displays profile $\mathrm{G}$, no differential displays profile $\mathrm{D}$ although it is seen in a minority of seedlings from multiple other accessions (PL 51559, PL 51818, PL 51841, PL 52106, PL 52205, PL 52209, PL 52278, and PL 52442). PL 52209 therefore seems likely to contain the novel specificity of profile D plus an additional new specificity of profile $\mathrm{F}$ in some seedlings, rather than one novel specificity plus $P c 46$.

The geographic distance between the original collection sites of the differentials and the accessions with similar profiles identified here also argues against the identity of the underlying genes. The

Table 5. Infection profiles (IPs) of screened Avena sterilis accessions based on the reaction to Puccinia coronata race infection

\begin{tabular}{|c|c|c|c|c|c|c|c|c|c|}
\hline \multirow[b]{2}{*}{ IP } & \multicolumn{5}{|c|}{ P. coronata race $^{\text {a }}$} & \multicolumn{2}{|c|}{$\begin{array}{c}\text { Seedlings that } \\
\text { displayed an IP }\end{array}$} & \multirow{2}{*}{$\begin{array}{l}\text { Defeated } \\
\text { genes }(n)\end{array}$} & \multirow{2}{*}{$\begin{array}{l}\text { Oat differential line with a } \\
\text { corresponding phenotype }\end{array}$} \\
\hline & CR241 & 94U & CR230 & $51 \mathrm{U}$ & CR257 & $n$ & $\%$ & & \\
\hline A & $\mathrm{H}$ & $\mathrm{H}$ & $\mathrm{H}$ & $\mathrm{H}$ & $\mathrm{H}$ & 247 & 60.24 & 5 & \\
\hline B & $\mathrm{L}$ & $\mathrm{H}$ & $\mathrm{H}$ & $\mathrm{H}$ & $\mathrm{H}$ & 2 & 0.49 & 4 & \\
\hline $\mathrm{C}$ & $\mathrm{H}$ & $\mathrm{L}$ & $\mathrm{H}$ & $\mathrm{H}$ & $\mathrm{H}$ & 40 & 9.76 & 4 & \\
\hline $\mathrm{D}$ & $\mathrm{H}$ & $\mathrm{H}$ & $\mathrm{L}$ & $\mathrm{H}$ & $\mathrm{H}$ & 21 & 5.12 & 4 & \\
\hline $\mathrm{E}$ & $\mathrm{H}$ & $\mathrm{H}$ & $\mathrm{H}$ & $\mathrm{L}$ & $\mathrm{H}$ & 15 & 3.66 & 4 & Pc36, Pc39, Pc55, Pc61, Pc70, Pc71 \\
\hline $\mathrm{F}$ & $\mathrm{H}$ & $\mathrm{H}$ & $\mathrm{H}$ & $\mathrm{H}$ & $\mathrm{L}$ & 6 & 1.46 & 4 & \\
\hline G & $\mathrm{H}$ & $\mathrm{H}$ & $\mathrm{L}$ & $\mathrm{H}$ & $\mathrm{L}$ & 6 & 1.46 & 3 & Pc46 \\
\hline $\mathrm{H}$ & $\mathrm{L}$ & $\mathrm{H}$ & $\mathrm{L}$ & $\mathrm{H}$ & $\mathrm{H}$ & 1 & 0.24 & 3 & \\
\hline I & $\mathrm{L}$ & $\mathrm{H}$ & $\mathrm{H}$ & $\mathrm{L}$ & $\mathrm{H}$ & 1 & 0.24 & 3 & \\
\hline K & $\mathrm{H}$ & $\mathrm{L}$ & $\mathrm{L}$ & $\mathrm{H}$ & $\mathrm{H}$ & 7 & 1.71 & 3 & \\
\hline $\mathrm{L}$ & $\mathrm{H}$ & $\mathrm{L}$ & $\mathrm{H}$ & $\mathrm{L}$ & $\mathrm{H}$ & 24 & 5.85 & 3 & Pc38, Pc63 \\
\hline M & $\mathrm{H}$ & $\mathrm{L}$ & $\mathrm{H}$ & $\mathrm{H}$ & $\mathrm{L}$ & 1 & 0.24 & 3 & Pc14 \\
\hline $\mathrm{N}$ & $\mathrm{H}$ & $\mathrm{H}$ & $\mathrm{L}$ & $\mathrm{L}$ & $\mathrm{H}$ & 1 & 0.24 & 3 & \\
\hline $\mathrm{U}$ & $\mathrm{H}$ & $\mathrm{L}$ & $\mathrm{L}$ & $\mathrm{L}$ & $\mathrm{H}$ & 1 & 0.24 & 2 & \\
\hline W & $\mathrm{H}$ & $\mathrm{L}$ & $\mathrm{L}$ & $\mathrm{H}$ & $\mathrm{L}$ & 3 & 0.73 & 2 & \\
\hline$S$ & $\mathrm{H}$ & $\mathrm{L}$ & $\mathrm{H}$ & $\mathrm{L}$ & $\mathrm{L}$ & 2 & 0.49 & 2 & \\
\hline $\mathrm{P}$ & $\mathrm{L}$ & $\mathrm{L}$ & $\mathrm{L}$ & $\mathrm{H}$ & $\mathrm{L}$ & 5 & 1.22 & 1 & Pc45, Pc101, Pc104, Pc51 \\
\hline $\mathrm{R}$ & $\mathrm{L}$ & $\mathrm{L}$ & $\mathrm{H}$ & $\mathrm{L}$ & $\mathrm{L}$ & 1 & 0.24 & 1 & Pc60, Pc91, Pc59 \\
\hline $\mathrm{X}$ & $\mathrm{L}$ & $\mathrm{L}$ & $\mathrm{L}$ & $\mathrm{L}$ & $\mathrm{H}$ & 3 & 0.73 & 1 & Pc56, Pc68 \\
\hline Y & $\mathrm{H}$ & $\mathrm{L}$ & $\mathrm{L}$ & $\mathrm{L}$ & $\mathrm{L}$ & 2 & 0.49 & 1 & Pc52 \\
\hline $\mathrm{T}$ & $\mathrm{L}$ & $\mathrm{L}$ & $\mathrm{L}$ & $\mathrm{L}$ & $\mathrm{L}$ & 21 & 5.12 & 0 & Pc58, Pc50 \\
\hline
\end{tabular}

${ }^{\mathrm{a}} \mathrm{H}=$ high infection (virulent reaction) and $\mathrm{L}=$ low infection (avirulent reaction).
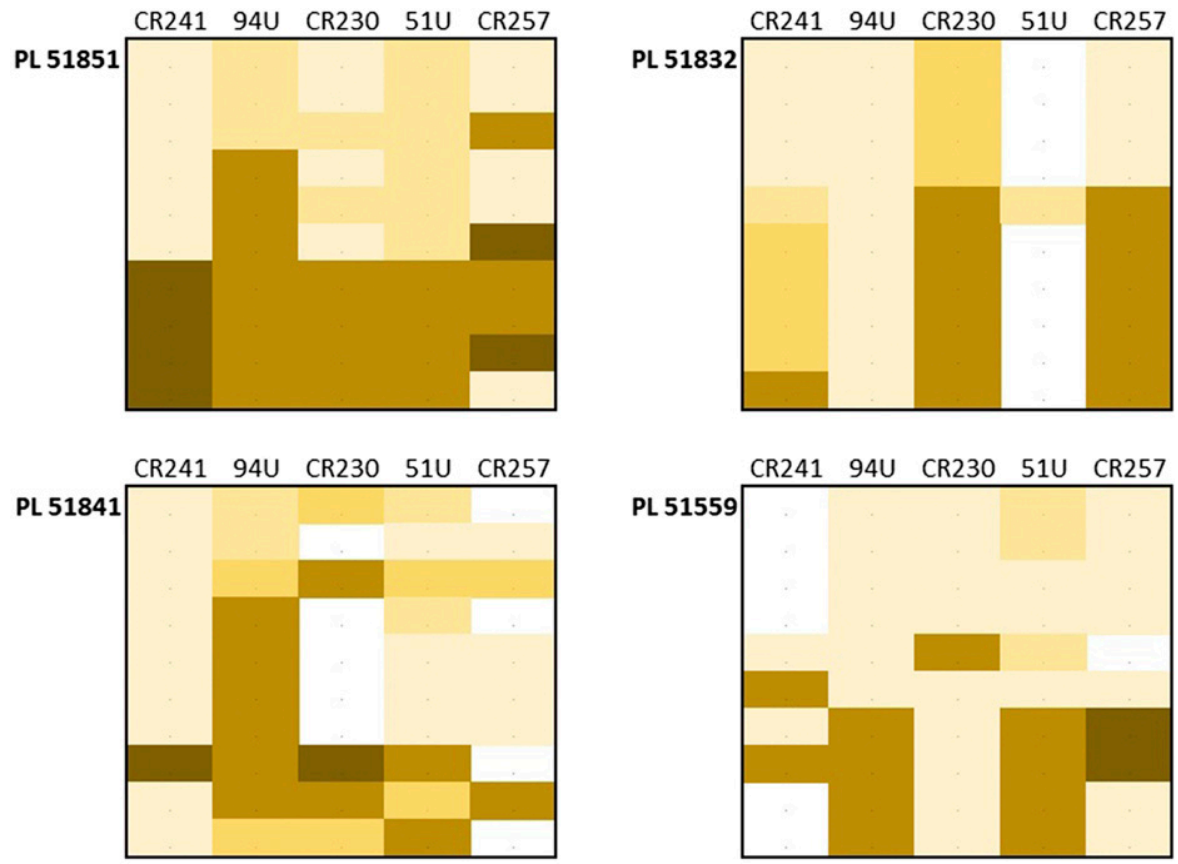

Fig. 2. Detailed scores of seedling responses for the most complex accessions. Scores range from 0 (highly resistant) to 4 (highly susceptible). Darker shading indicates higher resistance. 
complete resistance of accessions PL 51836 and PL 51851 resembles that of $P c 58$ and $P c 50$, but the differentials originate from Israel and Tunisia, respectively, 4,000 and $1,800 \mathrm{~km}$ from the collection site of PL 51836 (Tamanar, Morocco). Strikingly, Pc58 appears to be determined by multiple closely linked genes (Hoffman et al. 2006) and the long duration of its effectiveness in the field has been suggested to stem from these multiple genes, which the pathogen must overcome to break the resistance. A more detailed examination of the resistance profiles within the most heterogeneous accessions here suggests that multiple resistances may be combining in some populations to generate similar durable resistance (Fig. 2). All seedlings from PL 51836 display identical full resistance but seedlings from PL 51851 may be resistant to one, two, four, or five isolates. In one seedling, strong resistance to CR257 may be associated with partial resistance to 94U, CR230, and 51U. Full immunity is seen only against CR241 and CR257, and then only in some seedlings, consistent with development of QR within the population.

The most complex phenotypes, also suggestive of $\mathrm{QR}$, are seen in PL 51841. All seedlings show some degree of resistance but only three share a common profile, and only one seedling shows complete immunity to any isolates (here, to CR241 and CR230). Two seedlings show resistance to four isolates, each resembling a differential profile (Pc56/Pc68 and Pc52), but three seedlings show profiles $(\mathrm{C}$, $\mathrm{D}$, and $\mathrm{U})$ that are not exhibited by any differential lines or simple combinations of them. While this may reflect multiple new racespecific resistance specificities, an attractive alternative is that increasing levels of basal resistance have led to the emergence of enhanced QR variants within this population.

The strong resistance seen in PL 51855a was further characterized by crossing to three cultivars: Breton, Rajtar, and Kasztan. Resistance of $F_{2}$ and $F_{3}$ progeny was investigated. Leaf fragments of $F_{2}$ seedlings of all three populations were tested with three rust isolates: 3.2, 11.1, and CR230. Based on a resistant-to-susceptible segregation ratio of 3:1 in a minimum of 129 lines, it appeared that resistance in PL 51855a is conditioned by a single dominant locus (Table 6). The Kasztan population was advanced to the $\mathrm{F}_{3}$ generation and each line was assessed for resistance to three rust isolates: 3.2, 51U, and 94U. Leaf fragments from 10 seedlings of each line were used for each assessment. A consistent 1:2:1 ratio of resistant, segregating, and susceptible families confirmed the monogenic inheritance of resistance (Table 7). The broad range of protection provided by the PL 51855a locus was further confirmed by the use of additional rust pathotypes to screen the $\mathrm{F}_{3}$ progeny. These included the differentials for $P c 48$ and $P c 104$ and a further 50 pathotypes isolated from Polish field sites between 2015 and 2017 (Paczos-Grzęda et al. 2018). Two Polish isolates that overcame $P c 50$ (50_822) and Pc58 (58_172) were also tested (Table 1). None were able to overcome the resistant progeny.

\section{Discussion}

The virulent pathotypes recovered from the Polish field sites illustrate the challenge faced in attempting to protect crops through the use of race-specific major effect genes. Almost all available major effect genes have been overcome by these pathotypes, with additional virulence being found in other isolates from Europe or North America. New genes can be expected to be discovered for the foreseeable future, given the large numbers of wild relatives available in gene banks worldwide, but introgression into commercial backgrounds is time-consuming with even greater efforts required to transfer variants across ploidy barriers (Rines et al. 2017). Introduction of resistance that provides protection against broader ranges of pathotypes can be expected to be more durable and may be repeatedly strengthened by the addition of further resistance traits (Pilet-Nayel et al. 2017). In wild populations, dependence on major race-specific genes for resistance appears to be effective only transiently or for a small fraction of the population, and it is of interest to identify cases where alternative mechanisms have been selected. While QR by its nature is likely dependent on many genes of minor effect, there are also well-known examples of major effect genes that affect processes other than pathogen recognition, including the wheat genes Lr34 and Yr36 and the rice gene pi21 (Kourelis et al. 2018). The majority of these genes have been identified in cultivated material such as landraces where even partial resistance has been prized and selected over many years, in the face of evolving pathogen specificities. By contrast, most screens for resistance in crop wild relatives aim to identify the most resistant plants or accessions through stringent initial screens in the field or glasshouse using limited pathogen challenges, followed by broader characterization of resistance profiles of the chosen lines. This approach may allow many hundreds of accessions to be screened, but it may discard partial resistance phenotypes at an early stage. The high densities of inocula generated in disease nurseries may also overwhelm partial resistance that could be effective in normal field conditions (Leonard 2002).

The approach described here uses a reproducible in vitro method to compare responses to crown rust challenges within gene bank samples of wild Avena populations. It provides a more detailed analysis of relatively subtle differences in response than glasshouse or field

Table 6. $\mathrm{F}_{2}$ seedling segregation for crown rust reaction

\begin{tabular}{|c|c|c|c|c|c|c|c|}
\hline \multirow[b]{2}{*}{ Population } & \multirow[b]{2}{*}{ Puccinia coronata race } & \multicolumn{3}{|c|}{$F_{2}$ seedlings $(n)$} & \multirow[b]{2}{*}{ Expected ratio } & \multirow[b]{2}{*}{$\chi^{2}$} & \multirow[b]{2}{*}{$P$ value $^{\text {a }}$} \\
\hline & & Resistant & Susceptible & $\overline{\text { Total }}$ & & & \\
\hline \multirow[t]{3}{*}{ Rajtar $\times$ PL 51855a } & 3.2 & 96 & 33 & 129 & $3: 1$ & 0.232 & 0.630 \\
\hline & 11.1 & 90 & 39 & 129 & $3: 1$ & 1.884 & 0.170 \\
\hline & CR230 & 102 & 27 & 129 & $3: 1$ & 1.139 & 0.286 \\
\hline \multirow[t]{3}{*}{ Breton $\times$ PL 51855a } & 3.2 & 90 & 45 & 135 & $3: 1$ & 5.000 & 0.025 \\
\hline & 11.1 & 105 & 30 & 135 & $3: 1$ & 0.556 & 0.456 \\
\hline & CR230 & 99 & 36 & 135 & $3: 1$ & 0.200 & 0.655 \\
\hline \multirow[t]{3}{*}{ Kasztan $\times$ PL 51855a } & 3.2 & 102 & 36 & 138 & $3: 1$ & 0.087 & 0.768 \\
\hline & 11.1 & 102 & 36 & 138 & $3: 1$ & 0.087 & 0.768 \\
\hline & CR230 & 105 & 33 & 138 & $3: 1$ & 0.087 & 0.768 \\
\hline
\end{tabular}

${ }^{\mathrm{a}} \alpha=0.01$.

Table 7. $\mathrm{F}_{3}$ family segregation for crown rust reaction

\begin{tabular}{|c|c|c|c|c|c|c|c|c|}
\hline \multirow[b]{2}{*}{ Population } & \multirow[b]{2}{*}{ Puccinia coronata race } & \multicolumn{4}{|c|}{$F_{3}$ families $(n)$} & \multirow[b]{2}{*}{ Expected ratio } & \multirow[b]{2}{*}{$x^{2}$} & \multirow[b]{2}{*}{$P$ value $^{\text {a }}$} \\
\hline & & Resistant & Segregating & Susceptible & $\overline{\text { Total }}$ & & & \\
\hline \multirow[t]{3}{*}{ Kasztan $\times$ PL 51855a } & 3.2 & 90 & 209 & 72 & 371 & $1: 2: 1$ & 4.724 & 0.094 \\
\hline & $51 \mathrm{U}$ & 22 & 48 & 18 & 88 & $1: 2: 1$ & 0.727 & 0.695 \\
\hline & $94 \mathrm{U}$ & 21 & 51 & 27 & 99 & $1: 2: 1$ & 0.773 & 0.679 \\
\hline
\end{tabular}

${ }^{\mathrm{a}} \alpha=0.01$. 
screens of intact seedlings and adult plants, although it is less well suited to high-throughput screens aimed at recovering rare major effect variants. However, we have recovered at least one such gene from accession PL 51855a, and we believe that the approach is well suited to identifying populations displaying QR, which might otherwise be missed by "brute force" approaches. The use of detached leaf fragments allows simultaneous testing of multiple rust isolates on a single plant, an important consideration when genotypes may be mixed as for many gene bank accessions of wild or landrace material. Detached leaf assessment has been used for other cereal-fungal pathogen assays (Ames et al. 2015; Felsenstein et al. 1998; Osman-Ghani 1982; Turra et al. 2017) and was previously developed for oat, where the initial goal was propagation of multiple pure lines of Puccinia isolates (Jackson et al. 2008). The oat study demonstrated that detached leaf results were consistent with in vivo assessments of 16 differential lines. A number of media modifications were compared in order to maximize rust sporulation for propagation, with the synthetic cytokinin 6-Benzylaminopurine (BAP) being most effective. However, benzimidazole produced similar results and was employed here at a reduced concentration. While the authors of the oat study proposed that their method could be used to evaluate partial resistance, we believe that we are the first to carry out systematic surveys of oat germplasm resources with this approach (this work and PaczosGrzęda et al. 2018).

The method gives highly reproducible results, as demonstrated both by comparison of infection types seen for the various rust isolate and oat differential line combinations and for the specific responses seen within accessions (Figs. 1 and 2). For example, flecking was seen as a consistent response to pathotype $94 \mathrm{U}$ by the first three seedlings of PL 51856, while this was not seen in other accessions. The small number of response types seen within most accessions is therefore likely to reflect a limited number of resistance genes within the seedlings tested. By contrast, the complex responses seen within the small number of Moroccan accessions shown in Figure 2 suggests multiple genes and interactions, consistent with QR. QR is typically considered to be significant only for adult plants, while seedling resistance is seen as most probably resulting from race-specific recognition. There is no clear distinction, however, and it is clear that seedlings can be used to detect multiple partial resistance phenotypes. Use of seedlings considerably simplifies the logistics of these experiments.

Crown rust is a widespread disease of cultivated oat and its closely related species in Morocco. Areas with mild temperatures and an abundance of dew provide favorable conditions for the development of this disease and coincide with populations of the various wild Avena species and the alternate host, Rhamnus lycioides L., providing ideal opportunities to generate pathotype diversity. Saidi et al. (2005a) assessed the virulence of $P$. coronata $\mathrm{f}$. sp. avenae isolates collected from three regions of Morocco (Tangier, Gharb, and Doukkala) on 23 differential lines. All the sites of $P$. coronata collection were located in the northern or northwestern regions where crown rust is frequent and severe infections were reported (Rieuf 1971; Saidi et al. 2005a). The patterns of virulence were not different among the regions, but diversity within populations was high and 179 different virulence races or phenotypes were detected among the 197 samples analyzed. This diversity is expected to be reflected in the range of resistance exhibited by host populations (Flor 1971; Oates et al. 1983; Van der Hoorn et al. 2002). The complex responses seen in Figure 2 are consistent with significant levels of QR being present in the respective populations, with balanced selection preventing homogenization of genotypes. These responses should also be compared with the results from our screens of the weedy hexaploid $A$. fatua using the same methodology and $P$. coronata f. sp. avenae isolates (Paczos-Grzęda et al. 2018). From 204 accessions from 28 countries screened, only 17 displayed resistance to two or more isolates, with three of these being resistant to three isolates and only one being resistant to four. A. fatua is found in cultivated fields, usually among cereals, and the lack of broad resistance may reflect the different pathogen dynamics of this environment compared with the "natural" pressures acting on well-adapted A. sterilis populations.
The less complex responses seen in PL 51589 and PL 52110 in Figure 1 may reflect a real lack of QR in the populations from which the accessions were derived, but they may also be the result of a loss of diversity during sampling and multiplication in gene banks. Subsequent to our analyses, we discovered that both of these accessions were in fact donations from the U.S. National Small Grains Collection (PL 51589, originally designated PI 324822) and the Plant Gene Resources of Canada (PL 52110, originally designated CN 21856 and $\mathrm{CN}$ 67439). In other screens by us, the IHAR collections have also shown an unusually high level of heterogeneity compared with accessions from other gene banks (Paczos-Grzęda et al. 2018), suggesting that they have retained the original diversity of the sampled populations. Incorporating detached leaf screens at early rounds of multiplication of original collection material may help to identify and recover valuable resistance and select populations that may provide additional valuable material to help understand the levels and evolution of $\mathrm{QR}$ to crown rust in nature.

In conclusion, we see detached leaf assessments as a valuable first step in the screening of gene bank accessions where multiple genotypes may be expected, as is the case for wild populations and landraces. Both major effect and QR resistances may be detected, informing choices of material to be multiplied and used for more detailed studies, including population genetics and genome-wide association studies (GWAS) (Montilla-Bascón et al. 2015). The accessions PL 51855a, PL 51836, and PL 51851 contain broad resistance to a number of the most virulent current crown rust pathotypes. Resistance in accession PL 51855a appeared to be derived from a single locus and may be readily deployed to elite cultivars. Given the small number of accessions screened here, Moroccan A. sterilis populations are likely to be valuable sources of further broad-ranging resistance and merit further investigation.

\section{Acknowledgments}

We thank J. Menzies (Morden Research and Development Centre, AAFC) for providing crown rust isolates.

\section{Literature Cited}

Acevedo, M., Jackson, E. W., Chong, J., Rines, H. W., Harrison, S., and Bonman, J. M. 2010. Identification and validation of quantitative trait loci for partial resistance to crown rust in oat. Phytopathology 100:511-521.

Ames, N., Dreiseitl, A., Steffenson, B. J., and Muehlbauer, G. J. 2015. Mining wild barley for powdery mildew resistance. Plant Pathol. 64:1396-1406.

Boczkowska, M., Podyma, W., and Łapiński, B. 2016. Oat. Pages 159-225 in: Genetic and Genomic Resources for Grain Cereals Improvement. M. Singh and H. D. Upadhyaya, eds. Academic Press, San Diego, CA.

Brake, V. M., and Irwin, J. A. G. 1992. Partial resistance of oats to P. coronata f. sp. avenae. Aust. J. Agric. Res. 43:1217-1227.

Cabral, A. L., and Park, R. F. 2014. Seedling resistance to Puccinia coronata f. sp. avenae in Avena strigosa, A. barbata and A. sativa. Euphytica 196:385-395.

Carson, M. L. 2009. Broad-spectrum resistance to crown rust, Puccinia coronata f. sp. avenae, in accessions of the tetraploid slender oat, Avena barbata. Plant Dis. 93:363-366.

Carson, M. L. 2011. Virulence in oat crown rust (Puccinia coronata f. sp. avenae) in the United States from 2006 through 2009. Plant Dis. 95:1528-1534.

Cavan, G., Biss, P., and Moss, S. R. 1998. Herbicide resistance and gene flow in wild-oats (Avena fatua and Avena sterilis ssp. ludoviciana). Ann. Appl. Biol. 133:207-217.

Cereal Disease Laboratory. 2017. Resistance genes. Retrieved 4 October 2018 from https://www.ars.usda.gov/midwest-area/stpaul/cereal-disease-lab/ docs/resistance-genes/resistance-genes/

Chong, J., Gruenke, J., Dueck, R., Mayert, W., Mitchell Fetch, J. W., and McCartney, C. A. 2011. Virulence of Puccinia coronata f. sp. avenae in the eastern prairie region of Canada during 2007-2009. Can. J. Plant Pathol. 33: 77-87.

Chong, J., Leonard, K. J., and Salmeron, J. J. 2000. A North American system of nomenclature for Puccinia coronata f. sp. avenae. Plant Dis. 84:580-585.

Delph, L. F., and Kelly, J. K. 2014. On the importance of balancing selection in plants. New Phytol. 201:45-56.

Felsenstein, F. G., Park, R. F., and Zeller, F. J. 1998. The use of detached seedling leaves of Triticum aestivum to study pathogenicity in Puccinia recondita f. sp. tritici. J. Phytopathol. 146:115-121.

Fleischmann, G., McKenzie, R. I. H., and Shipton, W. A. 1971. Inheritance of crown rust resistance genes in Avena sterilis collections from Israel, Portugal, and Tunisia. Can. J. Genet. Cytol. 13:251-255.

Flor, H. H. 1971. Current status of the gene-for-gene concept. Annu. Rev. Phytopathol. 9:275-296. 
Gnanesh, B. N., Mitchell Fetch, J. M., Zegeye, T., McCartney, C. A., and Fetch, T. 2014. Oat. Pages 51-73 in: Alien Gene Transfer in Crop Plants, Volume 2: Achievements and Impacts. A. Pratap and J. Kumar, eds. Springer-Verlag, New York.

Harder, D. E., McKenzie, R. I. H., and Martens, J. W. 1980. Inheritance of crown rust resistance in three accessions of Avena sterilis. Can. J. Genet. Cytol. 22: 27-33.

Hoffman, D. L., Chong, J., Jackson, E. W., and Obert, D. E. 2006. Characterization and mapping of a crown rust gene complex (Pc58) in TAM O-301. Crop Sci. 46:2630-2635.

Hsam, S. L. K., Peters, N., Paderina, E. V., Felsenstein, F., Oppitz, K., and Zeller, F. J. 1997. Genetic studies of powdery mildew resistance in common oat (Avena sativa L.) I. Cultivars and breeding lines grown in Western Europe and North America. Euphytica 96:421-427.

Imam, A. G., and Allard, R. W. 1965. Population studies in predominantly selfpollinated species. VI. Genetic variability between and within natural populations of wild oats from differing habitats in California. Genetics 51: $49-62$

Jackson, E. W., Obert, D. E., Chong, J., Avant, J. B., and Bonman, J. M. 2008. Detached-leaf method for propagating Puccinia coronata and assessing crown rust resistance in oat. Plant Dis. 92:1400-1406.

Karasov, T. L., Horton, M. W., and Bergelson, J. 2014. Genomic variability as a driver of plant-pathogen coevolution? Curr. Opin. Plant Biol. 18:24-30.

Kim, H. B. 1974. Inheritance of resistance to Puccinia coronata var. avenae in six selections of Avena sterilis. Euphytica 23:174-180.

Kourelis, J., Renier, A. L., and van der Hoorn, R. A. L. 2018. Defended to the nines: 25 years of resistance gene cloning identifies nine mechanisms for $\mathrm{R}$ protein function. Plant Cell 30:285-299.

Leonard, K. J. 2002. Oat lines with effective adult plant resistance to crown rust. Plant Dis. 86:593-598.

Leonard, K. J., Anikster, Y., and Manisterski, J. 2004. Patterns of virulence in natural populations of Puccinia coronata on wild oat in Israel and in agricultural populations on cultivated oat in the United States. Phytopathol. 94:505-514.

Leonard, K. J., Huerta-Espino, J., and Salmeron, J. J. 2005. Virulence of oat crown rust in Mexico. Plant Dis. 89:941-948.

Lin, Y., Gnanesh, B. N., Chong, J., Chen, G., Beattie, A. D., Fetch, J. W. M., Kutcher, H. R., Eckstein, P. E., Menzies, J. G., Jackson, E. W., and McCartney, C. A. 2014. A major quantitative trait locus conferring adult plant partial resistance to crown rust in oat. BMC Plant Biol. 14:250.

Lindhout, P. 2002. The perspectives of polygenic resistance in breeding for durable disease resistance. Euphytica 124:217-226.

Loskutov, I. 2008. On evolutionary pathways of Avena species. Genet. Resour. Crop Evol. 55:211-220.

Loskutov, I., and Rines, H. W. 2011. Avena. Pages 109-183 in: Wild Crop Relatives: Genomic and Breeding Resources, Volume 1: Cereals. C. Kole, ed. Springer-Verlag, New York.

Marshall, D. R., and Brown, A. H. D. 1975. Optimum sampling strategies in genetic conservation. Pages 81-98 in: Crop Genetic Resources for Today and Tomorrow: International Biological Programme 2. O. H. Frankel and J. G. Hawkes, eds. Cambridge University Press, New York.

Martinelli, J. A., Federizzi, L. C., and Bennedetti, A. C. 1994. Redução do rendimento de grão da aveia em função da severidade da ferrugem da folha. Summa Phytopathol. 20:110-113.

Menzies, J. G., Xue, A., Dueck, R., and Greunke, J. 2015. Virulence of Puccinia coronata f. sp. avenae in Canada: 2010 to 2014. Page 95 in: Proceedings of the 14th International Cereal Rust and Powdery Mildew Conference. European and Mediterranean Cereal Rusts Foundation, Helsingør, Denmark.

Michelmore, R. W., and Meyers, B. C. 1998. Clusters of resistance genes in plants evolve by divergent selection and a birth-and-death process. Genome Res. 8:1113-1130.

Montilla-Bascón, G., Rispail, N., Sánchez-Martín, J., Rubiales, D., Mur, L. A. J., Langdon, T., Howarth, C. J., and Prats, E. 2015. Genome-wide association study for crown rust (Puccinia coronata f. sp. avenae) and powdery mildew (Blumeria graminis f. sp. avenae) resistance in an oat (Avena sativa) collection of commercial varieties and landraces. Front. Plant Sci. 6:103.

Mundt, C. C. 2014. Durable resistance: A key to sustainable management of pathogens and pests. Infect. Genet. Evol. 27:446-455.
Murphy, H. C. 1935. Physiologic specialisation in Puccinia coronata f. sp. avenae. Bull. U.S. Dep. Agric. 433:1-48.

Nazareno, E. S., Li, F., Smith, M., Park, R. F., Kianian, S. F., and Figueroa, M 2018. Puccinia coronata f. sp. avenae: A threat to global oat production. Mol. Plant Pathol. 19:1047-1060.

Niks, R. E., Qi, X., and Marcel, T. C. 2015. Quantitative resistance to biotrophic filamentous plant pathogens: Concepts, misconceptions, and mechanisms. Annu. Rev. Phytopathol. 53:445-470.

Oates, J. D., Burdon, J. J., and Brouwer, J. B. 1983. Interactions between Avena and Puccinia species. II. The pathogens: Puccinia coronata $\mathrm{Cda}$ and P. graminis Pers. f. sp. avenae Eriks. \& Henn. J. Appl. Ecol. 20:585-596.

Osman-Ghani, N. 1982. The uses and limitations of detached leaf culture for the assessment of reaction type in yellow rust of barley. Cereal Rusts Bull. 10: $16-21$

Paczos-Grzęda, E., Bednarek, P. T., and Koroluk, A. 2014. Avena sativa L. intercultivar polymorphism assessment using silicoDArT markers. Folia Pomer. Univ. Technol. Stetin. Agric. Aliment. Pisc. Zootech. 310:75-84.

Paczos-Grzęda, E., Sowa, S., Koroluk, A., and Langdon, T. 2018. Characteristics of resistance to Puccinia coronata f. sp. avenae in Avena fatua L. Plant Dis. 102:2616-2624.

Peturson, B. 1944. Adult plant resistance of some oat varieties to physiologic races of crown rust. Can. J. Res. 22c:287-289.

Pilet-Nayel, M. L., Moury, B., Caffier, V., Montarry, J., Kerlan, M. C., Fournet, S., Durel, C. E., and Delourme, R. 2017. Quantitative resistance to plant pathogens in pyramiding strategies for durable crop protection. Front. Plant Sci. 8:1838.

Portyanko, V. A., Chen, G., Rines, H. W., Phillips, R. L., Leonard, K. J., Ochocki, G. E., and Stuthman, D. D. 2005. Quantitative trait loci for partial resistance to crown rust, Puccinia coronata, in cultivated oat, Avena sativa L. [erratum published in Theor. Appl. Genet. 112:195-197]. Theor. Appl. Genet. 111: 313-324.

Rieuf, P. 1971. Parasites et saprophytes des plantes au Maroc. Cah. Rech. Agron. 30:520.

Rines, H. W., Miller, M. E., Carson, M., Chao, S., Tiede, T., Wiersma, J., and Kianian, S. F. 2017. Identification, introgression, and molecular marker genetic analysis and selection of a highly effective novel oat crown rust resistance from diploid oat, Avena strigosa. Theor. Appl. Genet. 131:721-733.

Saidi, S., Ez-zahiri, B., and Lepoivre, P. 2005a. Virulence analysis of crown rust (Puccinia coronata f. sp. avenae) of oats in Morocco. Al Awamia 114:3-20.

Saidi, S., Lepoivre, P., and Ez-zahiri, B. 2005b. Identification of resistance to crown rust in Moroccan wild oats. Al Awamia 115:52-72.

Šebesta, J., Zwatz, B., Roderick, H., Corazza, L., Manisterski, J., and Stojanovic, S. 2003. Incidence of crown rust and virulence of Puccinia coronata Cda. f. sp avenae Eriks. and the effectiveness of $P c$ genes for resistance in Europe, Middle East and North Africa. Arch. Phytopathol. Plant Prot. 36:179-194.

Simons, M. D. 1985. Crown rust. Pages 131-172 in: The Cereal Rusts, Volume 2: Diseases, Distribution, Epidemiology, and Control. A. P. Roelfs and W. R. Bushnell, eds. Academic Press, Orlando, FL.

Simons, M. D., Martens, J. W., McKenzie, R. I. H., Nishiyama, I., Sadanaga, K., Šebesta, J., and Thomas, H. 1978. Oats: A standardized system of nomenclature for genes and chromosomes and catalog of genes governing characters. U.S. Department of Agriculture Science and Education Administration and Iowa Agricultural and Home Economics Experiment Station, Washington, DC.

Sowa, S., Paczos-Grzęda, E., Koroluk, A., Okoń, S., Ostrowska, A., Ociepa, T., Chrząstek, M., and Kowalczyk, K. 2016. Resistance to Puccinia coronata f. sp. avenae in Avena magna, A. murphyi, and A. insularis. Plant Dis. 100: 1184-1191.

Steffenson, B. J., Olivera, P., Roy, J. K., Jin, A. Y., Smith, K. P., and Muehlbauer, G. J. 2007. A walk on the wild side: Mining wild wheat and barley collections for rust resistance genes. Aust. J. Agric. Res. 58: 532-544.

Tan, M. Y. A., and Carson, M. L. 2013. Screening wild oat accessions from Morocco for resistance to Puccinia coronata. Plant Dis. 97:1544-1548.

Thurston, H. D. 1971. Relationship of general resistance: Late blight of potato Phytopathology 61:620-626.

Turra, C., Reis, E. M., and Barcellos, A. L. 2017. Detached wheat leaf assay for assessing the sensitivity of Puccinia triticina races to fungicides. Summa Phytopathol. 43:181-185.

Van der Hoorn, R. A., De Wit, P. J., and Joosten, M. H. 2002. Balancing selection favours guarding resistance proteins. Trends Plant Sci. 7:67-71. 